\title{
How Country of Origin Influences Overall Brand Equity \\ ${ }^{1}$ Mohammad Ali Abdolvand, ${ }^{\text {*2}}$ Mahmood Ghanbari, ${ }^{3}$ Karim Mokhtari \\ ${ }^{1, * 2,3}$ Science and Research Branch, Islamic Azad University, Department of Business Management, Tehran, Iran \\ *Email: $\underline{\text { M_ghanbaribnd@yahoo.com }}$
}

\section{Received: 18th August 2017, Accepted: 01 ${ }^{\text {st }}$ January 2018, Published: 28th February 2018}

\begin{abstract}
The Present study is an attempt to explore how brand equity of branded cars is influenced by "the country-of-origin image". In this regard, the perception of Iranian consumers of Hyundai, country-of-origin of which is Korea, was measured. A conceptual framework was applied to investigate the influence of country-of-origin image upon dimensions of brand equity. One should note that brand equity includes brand loyalty, brand awareness/brand associations, perceived quality, and brand strength. Accordingly, 362 Iranians were sampled out of a selected university and they were interviewed face-to-face applying a structured questionnaire. It was revealed that evaluation of country image affects brand evaluation. Marketing measures should be taken to improve brand strength, perceived quality, awareness/association, and loyalty level. Country of origin is a multidimensional concept which must be taken into consideration for enhancing brand equity.
\end{abstract}

\section{Keywords}

Country-of-Origin; Perceived Quality Brand Awareness/Associations, Brand Loyalty, Brand Equity

\section{Introduction}

Today, the world has changed into a huge trading arena. Increasing demand for products that are out of reach in one hand, and the possibility to achieve the desired product for a less price somewhere else on the other hand ((O'Rourke \& Williamson, 2002)), as well as the constant exposure of consumers to a great deal of product information through packaging, branding, advertising, and other channels has intensified this trading. Using information supplied to consumers via above-mentioned channels, their preferences and purchase decisions are shaped. It as well stimulates certain kinds of emotions, feelings, imagery, and fantasies. It was Dichter (1962) who mentioned first the contribution of a product's country of origin to "the acceptance and success of products" (p. 116). Schooler (1956) empirically tested this hypothesis. He noticed a significant difference in acceptance of products that their only difference was their "made in" label (Verlegh et al., 1999). The impact of Country of Origin (COO) of brands on consumer perception has attracted wide attention since 1960's (Schooler, 1965; Ditchter,

1962) and has extensively been probed in marketing discipline (Peterson and Jolibert, 1995;
Papadopoulos and Heslop, 2002). Several studies (Leifeld, 1993; Peterson and Jolibert, 1995; Verlegh and Steenkamp, 1999) have stressed the significant impact of COO on consumers' brand perception and $\mathrm{COO}$ is a measure against which consumers evaluate the quality of the product. Personal experience or other sources form a product-country image for each consumer (Johans-son and Thorelli, 1985). These images associate peculiar products with peculiar countries, for example, Swiss watches, German Automobiles, Japanese electronics, USA appliances, etc.

As long as the country of origin of a single product turns multi-nation oriented, brand origin becomes an alternative for the general concept of country of origin (Jin et al., 2006). Building strong brands has several merits; therefore, it has come to limelight in marketing. It endows firms with an identity in the marketplace (Aaker, 1996), less vulnerability to competitive forces, larger margins, greater intermediary co-operation and support and opportunities of brand extension (Delgado- Ballester \& Munuera-Aleman, 2005). Accordingly, brand equity is the outcome of brand perception, which is in its turn influenced by many factors (Yasin, ET.al, 2007). Researchers and practitioners of marketing have become in the core of the investigation of "brand equity" to evaluate the overall value of a brand (Aaker, 1991; Baldinger, 1990; Keller, 1993).

Cordell (1992) argues those product brands which belong to a country of high competence image are preferred to those which come from a country of less favorable competence. Besides, Cordell (1992) believes when consumers know a brand, they do not take $\mathrm{COO}$ in to account to evaluate the particular product. COO studies (Kim and Chung, 1997; Hui and Zhou, 2003) relate brand names to quality connotations. Country of origin usually implies product quality (Lusk et al., 2006). Once there is missing information and consumers have not yet actually consumed the product to be able to evaluate it, they rely on country of origin as a measure of quality. They judge the quality of the product based on a country's reputation (Lusk et al., 2006). The multi-dimensional effect of country of origin image influences product beliefs and attitudes for brands with different levels of equity (Hui and Zhou, 2003). However, it occurs that when a product is manufactured in a country with lower images than the country of bran origin, products will be 
negatively evaluated. According to Thakor and Lavack (2003), these researchers acknowledged that brand origin has a significant role in determining brand image. Several studies indicate country-oforigin's (Coo) direct influence towards brand equity (Yasin et al., 2007). The information-processing theory postulates that consumers evaluate a product and decide to purchase it applying different cues. In general, the country-of-origin is an important external cue (Thorelli et al., 1989). Hence, Pappu et al. (2006) stress that marketing managers who are active in international arena must recognize the roots of brand equity, and understand the importance of taking the country of origin into account for measuring brand equity. Recognizing the links between brand equity and country of origin is beneficial. Researchers believe managers must preserve the "core essence of a brand" in their international branding decisions (de Chernatony et al., 1995). "The 'essence' of the brand is easily perceived and placed value by consumer" (Arnold, 1992, p. 17).

Marketing managers should find a way to keep the core essence of their brands across international boundaries so as to survive in international competitions. Understanding the way country of origin impacts upon brand equity and its relevant dimensions (e.g. Perceived quality, brand associations), marketing researchers will be equipped with appropriate means to improve the core essence of a brand. Furthermore, a better understanding of the impact of country of origin information upon brand equity is as well precious for marketing practitioners since they mind "quantification of brand equity" and " identification of elements that will likely change consumer behavior and brand equity". (Biel, 1993, p. 77) found that Japanese brands of automobiles (Honda/Mazda) made in Korea/Mexico/ the Philippines were perceived less attractive in comparison with the time they were made in Japan. By the same token, Nebenzahl and Jaffe (1996) revealed that Sony lost its brand attractiveness when made in the USA, whereas GE's brand image enhanced when produced in Japan. Since both country of origin and brand equity influence upon consumers choice, the present study investigates the contribution of brand's country of origin to the shape of brand equity. To this end, the brand equity of automobile, in Iran market was explored. It is attempted in this study to reach to a better understanding of the impact of country of origin on the brand equity.

\section{Conceptualization and Hypotheses Brand Equity and its Dimensions}

Brand equity, introduced in 1980's, has become a key concept and a main field of research in marketing (Ambler, 2003; Samli \& Fevrier, 2008;
Buil et al., 2013). Globalization and intensified competition have even strengthened it (Pinar et al., 2014). From financial, consumer-based, or holistic perspective it was attempted to define and conceptualize it (Aaker, 1991; Srinivasan et al., 2005; Keller, 1993, 2008). The brand's financial value depends on how consumers react to it (Christodoulides \& de Chernatony, 2010). In other words, if a brand is not welcome by customer, it means it does not exist in the market and has no financial value (Keller, 1993; Pappu et al., 2005). Thus, most studies chose consumer-based perspective to define brand equity.

Although various definitions have been proposed for brand equity, there is still no consensus around what it actually means (Park and Srinivasan, 1994). There is either no general agreement among researchers about what it involves. Farquhar (1989) broadly defined brand equity as the value brand gives to the product. Majority of definitions are similar to what Farquhar stated (e g. Yoo and Donthu, 2001). Existing definitions can be categorized into two groups. Some are relied on financial perspective and specify the value a brand brings for a firm (e $\mathrm{g}$. Simon and Sullivan, 1993). Others are relied on consumer-perspective, which consider brand equity as the brand's value for customers (Rangaswamy et al., 1993). When brand equity reflects a consumer or marketing perspective, its equity is called consumerbased equity.

One important prerequisite for creating brand equity is brand awareness i.e. the familiarity with an awareness of brand existence (Kapferer, 2008). The awareness is mainly correlated with quality, trust, reliability, closeness to people and accessibility of the product (Kapferer,2008:21) and is measured in two ways; Brand associations: in the management of brand equity, brand association is an important step (Till, Baack and Waterman, 2011), and has a significant role in brand building (Knox and Bickerton, 2000). Brand association is called "the heart and soul of brand" (Aake, 1996:8 cited in Till et al., 2011) and critical to the understanding of customer-based equity" (Hsieh 2004:33, cited in Till et al., 2011). The conceptualization of brand association is " "anything connected to memory to a brand', 'a set of [brand] associations, usually in some meaningful, p.109). Brand associations consist of brand beliefs and attitudes entailing the perceived advantages of a certain brand (Keller, 1993; Netemeyer et al., 2004).

One more important criterion for brand judgment is perceived quality which indicates customers' personal estimation of the brand (Keller, 2001, p. 13-14). Perceived quality is different from the real quality of a brand since if a consumer had disagreeable experience with a brand in the past will judge negatively about that product in the future (Hsin et al. 2009, p. 136; Aaker 1996). Perceived 
quality is made up of situational, comparative, and individual components. It is affected by a broad range of factors such as perceived risk, education level, and previous experience and situational variables including social background of consumers, time pressure, purchase situation, and purchase intention (Holbrook \& Corfman, 1985). Garvin (1983) suggests that intrinsic and extrinsic cues that underlie consumers' evaluation impact upon perceived quality (Olshavsky, 1985; Zeithaml, 1988).

Aaker defines brand strength as differentiation multiplied by relevance. If a brand enjoys both attributes, it is logically regarded strong (Aaker, 1996). The Young and Rubicam model showed four aspects, namely differentiation, relevance, esteem, and knowledge make up a brand successively (Aaker, 1996). According to Interbrand method, variables such as leadership, stability, internationality, protection, support, trend, and market determine the strength of a brand (Moorthi, 2003). In the present study, variables proposed by Interbrand method are regarded to determine brand strength. Brand loyalty refers to a customer's attachment to a brand (Aaker, 1991:39, cited in Jung and Sung, 2006), and as Yasin, Noor and Mohamad (2007) and Aaker (1993) stated, brand loyalty substantially establishes the value of brand equity. Consumer's loyalty to a brand is embodied either behaviorally by his intention to repeat the purchase or attitudinally through their perception of attractiveness, active engagement, and brand's attachment (Martensen and Gronhold, 2010). Chi et al (2009) argued that the main objective of brand management is brand loyalty so that consumers still prefer a brand to its competitors

\section{Country of Origin (COO)}

Traditionally, country of origin is called as home country and as Saeed (1994) puts, it is the country to which a product or brand is ascribed. Previous studies show that consumer perceptions, preferences, purchase intention, choices and overall product evaluation are all impacted by this concept (Bilkey \& Nes, 1982; Han \& Terpstra, 1988; Peterson \& Jolibert, 1995; Yasin et al., 2007). There is a close tie between country-oforigin and country image. Nagashima (1970) introduced country image in his pioneering work. His definition of country image is as follows;

Country image is defined as the picture, the stereotype and the reputation and is associated with products of a certain country. Variables including national characteristics, representative product, history, economic and political background and traditions form such an image.

Following the definition of Schooler (1965), COO has always been referred to as "the country of manufacture or assembly" (Prendergast et al., 2010;
Bamber et al., 2011) but as a result of globalization, $\mathrm{COO}$ effect has been proved to affect international competitions (Bamber et al., 2011). Furthermore, binational/hybrid products and brands have appeared as a result of the development of multi-national organizations and huge foreign direct investments in underdeveloped and developing countries with the aim of reducing operational costs and lower wage rates (Haubl \& Elrod, 1999, Prendergast et al., 2010). $\mathrm{Bi}$-national/hybrid product is the one which is designed in one country, manufactured somewhere else, and assembled again in a third country; whereas, the brand belongs to a fourth country (Bilkey \& Nes, 1982; Chao, 1993; Ulgado \& Lee, 1993; Prendergast et al.,2010; Fetscherin \& Toncar, 2010; Ahmed et al., 2012; Saeed et al., 2013). COO should no longer be considered as a simple but instead as a multi-dimensional concept because present technological advances enable customers to associate various countries with a single brand (Bamber et al., 2011). As a natural consequence, consumers' perception of hybrid products is more intricate (Chen \& Su, 2012). Hence, country of origin image (COI), or country image, either denotes a group of associations of a home country that is organized in a meaningful way (Kotler et al., 1993), or it refers to one's attitude toward a specific country (Martin and Eroglu, 1993). In fact, the image of a country must not be mistaken with the image of products of that country (Martin and Eroglu, 1993). Yasin et al. (2007) carried out separate regression analyses to test the impact of brand distinctiveness and brand awareness/associations on brand loyalty and the relationship between country of origin image and brand equity. Hoeffler and Keller (2003) demonstrated a number of advantages of brand strength related to stronger positive impacts upon consumers' evaluations and behavior. The expectation is that strong brands (i.e., brands with an established image and significant brand equity) be more "resistant" to COO misclassification since consumer choice is more likely to be impacted by brand name rather than the associated COO (Cordell 1992, 1993; Tse and Lee1993). However, a great deal of empirical evidence indicates that a brand's $\mathrm{COO}$ effects on brand equity (Pappu, Quester, and Cooksey 2006; Yasin, Noor, and Mohamad2007). Besides, a favorable brand cannot counter balance a negatively perceived COO (Ahmed et al. 2002).

The relationship between country of origin and brand loyalty is understudied and there is not much insight in this regard. However, it is presumed that country-of-origin could influence brand loyalty, which is one of the components of brand equity. Brand loyalty refers to consumer's inclination to prefer a certain brand to others. Yasin et al. (2007) pinpointed a positive correlation between $\mathrm{COO}$ and brand loyalty among Malaysian consumers of electrical appliances and proved that a favorable image of COO results in stronger loyalty. Further, 
Shahin et al. (2013) detected COO had the greatest impact on brand loyalty as opposed to brand image and brand awareness. Last but not least, Murtiasih et al. (2014) demonstrated accordingly that COO effect on brand equity is greater through brand loyalty rather than perceived quality within the car market of Indonesia and a significant positive association between $\mathrm{COO}$ and $\mathrm{CBBE}$ dimensions was confirmed.

It was found in this study that country of origin positively impacts upon brand equity. Yasin et al. (2007) investigated the impact of country-of-origin image on building brand equity and found that a brand's country of origin leaves a positive and significant effect on brand equity dimensions. Research hypotheses are postulated as follows;

H1: The country image positively influences brand awareness/brand Associations

$\mathrm{H} 2$ : The country image positively influences perceived quality

H3: The country image positively influences brand strength

H4: The country image positively influences brand loyalty

H5: Brand awareness and brand associations positively influence brand equity

H6: Perceived quality positively influences brand equity

H7: brand strength positively influences brand equity

H7: Brand loyalty positively influences brand equity

Hypotheses mentioned in the above are outlined in research model illustrated in Fig. 1.

Figure 1: Research Conceptual Model

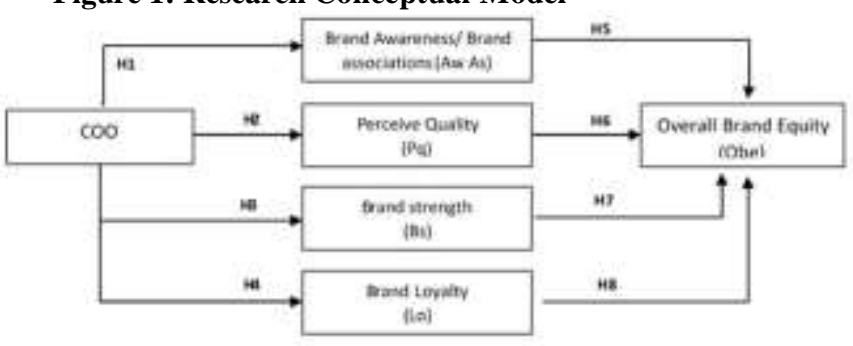

\section{Methodology}

To collect the required data, a structured questionnaire was designed based on five-point Likert scale. Items were rated from 1 (strongly disagree) to 5 (strongly agree). The cognitive component of the country of origin (COO) entailed eight items based on studies of Shirin (2011). The multidimensional brand equity (MBE) included ten items and overall brand equity was measured by four items adopted from Yoo and Donthu (2001). Items of the MBE model include perceived quality, brand awareness/association and brand loyalty. Nath, Sanyal, and Datta (2011) measured brand strength by 7 statements (I like better brand A which demonstrates leadership, I like better brand A with quality of firmness, I would rather brand A that is accepted deliberately, I like better brand A that is actively promoted and supported by the firm, I would rather brand A that is adequately protected by trademark, I would rather brand A that works in a stable market, I would rather brand A that indicates futuristic trend).

Sampling Method and Sample Size: the total population of Iran's selected students consisted of 1000 students of three different majors such as Mechanic engineering and accounting and management. Sampling was done through random sampling methods and proportional stratified sampling. Initially, questionnaires were given to respondents according to Proportional Stratified sampling, relative to the numbers of colleges. In the next step, at college entrance gate, systematic random sampling was carried out to choose the participants. Regarding the size of the sample, 400 questionnaires were given, out of which 362 ones were completed. It must be noted that 184 questionnaires were about Korean vehicles and 178 ones were for Iranian ones.

Reliability and Validity Analysis: Alpha Cronbach was applied for assessing the reliability of the questionnaire. The overall value of Cronbach Alpha was 0.874 . To this end, a pre-test was done on a sample including 55 respondents and 50 questionnaires were completed. It was revealed that the Cronbach value of each variable was over 0.7 . Since the least significant reliability for research questionnaire is 0.7 , this questionnaire was found reliable (Hair et al., 2013).

\section{Results and Discussion}

To test the validity and credibility of the scales, LISREL was used. To conduct Confirmatory factor analysis, structural equations modeling was used. Confirmatory factor analysis was also employed for the scales validity measurment (Steenkamp \& van Trijp, 1991). The model used for measuring entails 29 items by which 5 latent variables have been defined such as, Brand Awareness / Brand Associations (Aw/As), Country of Origin Image (Coo), Perceived Quality (Pq), Brand Strength (Bs), Brand Loyalty (Lo) and Overall Brand Loyalty (Obe). CFA is an extended kind of Explanatory Factor Analysis (EFA) (Lee, 2007). It is also a type of SEM dealing with the measuring models of the relations between latent variables, or factors and observed measurements or indicators (test items, test scores, etc.). 


\section{Hypothesis Testing}

As shown in table 1, all hypotheses are verified because in all cases, $t$-values and path coefficients were estimated positive and greater than 1.96 respectively.

Table 1: Hypothesis Testing Results

\begin{tabular}{|c|c|c|c|}
\hline Hypothesis & B & t-value & Results \\
\hline H1 & 0.64 & 7.85 & Verified \\
\hline H2 & 0.63 & 8.77 & Verified \\
\hline H3 & 0.73 & 8.84 & Verified \\
\hline H4 & 0.77 & 9.86 & Verified \\
\hline H5 & 0.29 & 3.38 & Verified \\
\hline H6 & 0.22 & 2.37 & Verified \\
\hline H7 & 0.31 & 3.39 & Verified \\
\hline
\end{tabular}

Fitting Indices and Goodness of Fit

In terms the model's goodness- of-fit, all six indices have gained required range approximately. Therefore, our research model enjoys appropriate goodness of fit (see table 2).

\begin{tabular}{|c|c|c|c|c|c|}
\hline $\begin{array}{c}\text { Fitting } \\
\text { indexes }\end{array}$ & $\frac{\boldsymbol{\chi}^{\mathbf{2}}}{\mathbf{d f}}$ & NFI & IFI & AGFI & RMSEA \\
\hline $\begin{array}{c}\text { Accepted } \\
\text { ranges }\end{array}$ & $1-5$ & $>0.9$ & $0-1$ & $>0.9$ & $<0.5$ \\
\hline Estimates & 1.72 & 0.94 & 0.98 & 0.86 & 0.87 \\
\hline
\end{tabular}

Table 2: Fitting Indices

\section{Managerial Implications}

The present study was an investigation of the impacts of the country-of-origin image on the development of brand equity of automobile Iran market. It was revealed that the brand equity of automobile encompasses four dimensions, namely perceived quality, brand strength, brand loyalty, and brand awareness/associations. These four aspects leave a significant effect on brand equity as hypothesized. It is therefore concluded that the formation of brand equity is rooted in these dimensions. The research model applied in this study was tested for Hyundai that is a brand of Korea origin. This model proved to have significant implications in sampling Iranian consumers. To put it differently, the evaluations and behavioral intentions of the Iranian consumers for the Korea brands was dependent on the effect of the country image. Car manufacturers must focus on the brand to stabilize and remain in the market longer. They can benefit from the country of origin image providing they stress the higher quality of their brands which derives from a particular country. Establishing brand equity in Iran market will improve promotional strategies of car companies. Besides, product type as well effects on applying country of origin attribute. Thus, this effect varies from one product to the other. Generally, high involvement products are more pertinent to the concept of country of origin. It was found that there is a high correlation between discussed variables. The effect of country of origin on consumers cannot be easily manipulated by marketers but taking proper marketing strategies will help to shape brand image in consumer minds. One of the limitations of this research was the fact that only a very specific type of product, i.e. branded automobiles was analyzed.

\section{References}

1. Aaker, D. A. (1991). Managing Brand Equity. New York, NY: Macmillan.

2. Aaker, D. A. (1996). Building Strong Brands. New York, NY: The Free Press.

3. Aaker, D. A., \& Biel, A. (2013). Brand equity \& advertising: advertising's role in building strong brands: Psychology Press.

4. Ahmed, Z. U., Zbib, I. J., Sikander, A., \& Gilbert Noujaim, R. (2012). Does country of brand origin (COBO) matter for the Lebanese consumers? EuroMed Journal of Business, 7(2), 108-128.

5. Ambler, T. (2003). Marketing and the bottom line: the marketing metrics to pump up cash flow: Pearson Education.

6. Arnold, D. (1992). The handbook of brand management: Basic Books.

7. Baldinger, A. L. (1990). Defining and Applying the Brand Equity Concept. Journal of Advertising Research, 3, P2. Bamber, D., Phadke, S., \& Jyotishi, A. (2011). Product-knowledge, ethnocentrism and purchase intention: COO Study in India. Global Markets and Workforce.

8. Baumgartner, H., \& Homburg, C. (1996). Applications of structural equation modeling in marketing and consumer research: A review. International Journal of Research in marketing, 13(2), 139-161.

9. Bentler, P. M. (1990). Comparative fit indexes in structural models. Psychological bulletin, 107(2), 238.

10. Biel, A. L. (1993). Converting image into equity. Brand equity and advertising: Advertising's role in building strong brands, 67-82.

11. Bilkey, W. J., \& Nes, E. (1982). Countryof-origin effects on product evaluations.

12. Bilkey, W. J., \& Nes, E. (1982). Countryof-origin effects on product evaluations.

13. Brasco, T. C. (1988). How brand names are valued for acquisition. Paper presented at the Defining, measuring and managing brand equity: A conference summary report.

14. Buil, I., Martínez, E., \& de Chernatony, L. (2013). The influence of brand equity on 
consumer responses. Journal of Consumer Marketing, 30(1), 62-74.

15. Chaimanat, P., \& Rackchamroon, $P$. (2011). Influences of the country of origin in Thai consumers' buying decision toward beer purchasing.

16. Chao, P. (1993). Partitioning country of origin effects: consumer evaluations of a hybrid product. Journal of International business studies, 291-306.

17. Chen, C.-F., \& Tseng, W.-S. (2010). Exploring customer-based airline brand equity: Evidence from Taiwan. Transportation Journal, 24-34.

18. Cordell, V. V. (1992). Effects of consumer preferences for foreign-sourced products. Journal of International business studies, 251-269.

19. Cordell, V. V. (1993). Interaction effects of country of origin with branding, price, and perceived performance risk. Journal of International Consumer Marketing, 5(2), 520.

20. De Chernatony, L., Halliburton, C., \& Bernath, R. (1995).

21. International branding: demand-or supply-driven opportunity? International Marketing Review, 12(2), 9-21.

22. Delgado-Ballester, E., \& Luis MunueraAlemán, J. (2005).Does brand trust matter to brand equity? Journal of Product \& brand management, 14(3), 187-196.

23. Dichter, E. (1962). The world customer. Harvard Business Review, 40(4), 113-122.

24. Erickson, G. M., Johansson, J. K., \& Chao, P. (1984). Image variables in multiattribute product evaluations: country-oforigin effects. Journal of consumer research, 11(2),694-699.

25. Farquhar, P. H. (1989). Managing brand equity. Marketing research, 1(3).

26. Fetscherin, M., \& Toncar, M. (2010). The effects of the country of brand and the country of manufacturing of automobiles: An experimental study of consumers' brand personality perceptions. International Marketing Review, 27(2), 164-178.

27. Floyd, F. J., \& Widaman, K. F. (1995). Factor analysis in the development and refinement of clinical assessment instruments. Psychological assessment, 7(3), 286.

28. Garvin, D. (1983). Quality on the line. Harv. Bus. Rev., 65-75. Han, C. M., \& Terpstra, V. (1988). Country-of-origin effects for uni-national and bi-national products.

29. Hair, J. F., Hult, G. T. M., Ringle, C., \& Sarstedt, M. (2013). A primer on partial least squares structural equation modeling (pls-sem). Sage Publications.

30. Han, C. M., \& Terpstra, V. (1988). Country-of-origin effects for uni-national and bi-national products.

31. Häubl, G., \& Elrod, T. (1999). The impact of congruity between brand name and country of production on consumers' product quality judgments. International Journal of Research in marketing, 16(3), 199-215.

32. Hoeffler, S., \& Keller, K. L. (2003). The marketing advantages of strong brands. The Journal of Brand Management,10(6), 421-445.

33. Holbrook, M. B., \& Corfman, K. P. (1985). Quality and value in the consumption experience: Phaedrus rides again. Perceived quality, 31(2), 31-57.

34. Hong, S.-T., \& Wyer Jr, R. S. (1989). Effects of country-of-origin and productattribute information on product evaluation: An information processing perspective. Journal of consumer research, 16(2), 175-187.

35. Hsieh, M. H. (2002). Identifying brand image dimensionality and measuring the degree of brand globalization: A crossnational study. Journal of International Marketing, 10(2),46-67.

36. Hui, M. K., \& Zhou, L. (2003). Country-ofmanufacture effects for known brands. European journal of marketing, 37(1/2), 133-153.

37. Jin, Z., Chansarkar, B., \& Kondap, N. (2006). Brand origin in an emerging market: perceptions of Indian consumers. Asia Pacific Journal of Marketing and Logistics, 18(4),

38. 283-302.

39. Johansson, J. K., \& Thorelli, H. B. (1985). International product positioning. Journal of International business studies, 16(3), 57-75.

40. Johansson, J. K., \& Nebenzahl, I. D. (1986). Multinational production: effect on brand value. Journal of International business studies, 101-126.

41. Johansson, J. K., \& Nebenzahl, I. D. (1986). Multinational production: effect on brand value. Journal of International business studies, 101-126.

42. Johansson, J. K., \& Nebenzahl, I. D. (1986). Multinational production: effect on brand value. Journal of International business studies, 101-126.

43. Kapferer, J.-N. (2008). The New Strategic Brand Management: Creating and Sustaining Brand Equity 
44. Keller, K. L. (1993). Conceptualizing, measuring, and managing customer-based brand equity. The Journal of Marketing, 122.

45. Keller, K. L. (1993). Conceptualizing, measuring, and managing customer-based brand equity. The Journal of Marketing, 122.

46. Keller, K. L., Parameswaran, M., \& Jacob, I. (2011). Strategic brand management: Building, measuring, and managing brand equity: Pearson Education India.

47. Kim, C. K., \& Chung, J. Y. (1997). Brand popularity, country image and market share: an empirical study. Journal of International business studies, 361-386.

48. Kim, D., \& Lehmann, D. (1989). The role of brand equity in modeling the impact of advertising and promotion on sales. Columbia University.

49. Kim, H.-b., Gon Kim, W., \& An, J. A. (2003). The effect of consumer-based brand equity on firms' financial performance. Journal of Consumer Marketing, 20(4), 335-351.

50. Knox, S., \& Bickerton, D. (2003). The six conventions of corporate branding. European journal of marketing,37(7/8), 998-1016.

51. Krejcie, R. V., \& Morgan, D. W. (1970). Determining sample size for research activities. Educational and psychological measurement, 30(3), 607-610.

52. Lee, H.-M., \& Lee, C.-C. (2011). Countryof-origin and brand redeployment impact after brand acquisition. Journal of Consumer Marketing, 28(6), 412-420.

53. Leuthesser, L. (1988). Defining, Measuring, and Managing Brand Equity: A Conference Summary by: Marketing Science Institute.

54. Liefeld, J. P. (1993). Experiments on country-of-origin effects: Review and meta-analysis of effect size. Productcountry images: Impact and role in international marketing, 1, 17-56.

55. Lusk, J. L., Brown, J., Mark, T., Proseku, I., Thompson, R., \& Welsh, J. (2006). Consumer behavior, public policy, and country-of-origin labeling. Review of agricultural economics, 28(2), 284-292.

56. Mahajan, V., Muller, E., \& Bass, F. M. (1990). New product diffusion models in marketing: A review and directions for research. the Journal of Marketing, 1-26.

57. Martin, I. M., \& Eroglu, S. (1993). Measuring a multi- dimensional construct: Country image. Journal of business research, 28(3), 191-210.
58. Mohd Yasin, N., Nasser Noor, M., \& Mohamad, O. (2007).Does image of country-of-origin matter to brand equity? Journal of Product \& brand management, 16(1), 38-48.

59. Murtiasih, S., Sucherly, S., \& Siringoringo, H. (2014). Impact of country of origin and word of mouth on brand equity. Marketing Intelligence \& Planning, 32(5), 616-629.

60. Nagashima, A. (1970). A comparison of Japanese and US attitudes toward foreign products. the Journal of Marketing, 68-74.

61. Narasimhan, R., \& Jayaram, J. (1998). Causal linkages in supply chain management: an exploratory study of North American manufacturing firms. Decision sciences, 29(3), 579-605.

62. Nath Sanyal, S., \& Datta, S. K. (2011). The effect of country of origin on brand equity: an empirical study on generic drugs. Journal of Product \& brand management, 20(2),130-140.

63. Nebenzahl, I. D., \& Jaffe, E. D. (1996). Measuring the joint effect of brand and country image in consumer evaluation of global products. International Marketing Review, 13(4),5-22.

64. O'rourke, K. H., \& Williamson, J. G. (2002). When did globalisation begin? European Review of Economic History, 6(1), 23-50.

65. Osgood, C. E., \& Tannenbaum, P. H. (1955). The principle of congruity in the prediction of attitude change. Psychological review, 62(1), 42.

66. Papadopoulos, N., \& Heslop, L. (2002). Country equity and country branding: Problems and prospects. The Journal of Brand Management, 9(4), 294-314.

67. Pappu, R., Quester, P. G., \& Cooksey, R. W. (2006).Consumer-based brand equity and country-of-origin relationships: some empirical evidence. European journal of marketing, 40(5/6), 696-717.

68. Pappu, R., Quester, P. G., \& Cooksey, R. W. (2007). Country image and consumerbased brand equity: relationships and implications for international marketing. Journal of International business studies, 726-745.

69. Park, C. S., \& Srinivasan, V. (1994). A survey-based method for measuring and understanding brand equity and its extendibility. Journal of Marketing Research, 271-288.

70. Peterson, R. A., \& Jolibert, A. J. (1995). A meta-analysis of country-of-origin effects. Journal of International business studies, 883-900. 
71. Phau, I., \& Suntornnond, V. (2006). Dimensions of consumer knowledge and its impacts on country of origin effects among Australian consumers: a case of fast-consuming product. Journal of Consumer Marketing, 23(1), 34-42.

72. Pinar, M., Trapp, P., Girard, T., \& E. Boyt, T. (2014).University brand equity: an empirical investigation of its dimensions. International Journal of Educational Management, 28(6), 616-634.

73. Rackchamroon, P., \& Chaimanat, P. (2011). Influences of the country of origin in Thai consumer's buying decision toward beer purchasing.

74. Rangaswamy, A., Burke, R. R., \& Oliva, T. A. (1993). Brand equity and the extendibility of brand names. International Journal of Research in marketing, 10(1), 61-75.

75. Samli, A. C., \& Fevrier, M. (2008). Achieving and managing global brand equity: a critical analysis. Journal of global marketing, 21(3), 207-215.

76. Schooler, R. D. (1965). Product bias in the Central American common market. Journal of Marketing Research, 394-397. Shahin, A., Kazemi, A., \& Mahyari, H. (2012). How consumer's perception of the country of origin affects brand equity: A case study in Iran. Middle-East Journal ofScientific Research, 12(6), 878-885.

77. Shimp, T. A., Samiee, S., \& Madden, T. J. (1993). Countries and their products: a cognitive structure perspective. Journal of the Academy of Marketing Science, 21(4), 323-330.

78. Shocker, A. D., Srivastava, R.K. and Rueckert, R.W. (1994).

79. Challenges and opportunities facing brand management: an introduction to the special issue. Journal of Marketing Research, 31, May, pp. 149-158.

80. Shocker, A. D., \& Weitz, B. (1988). A perspective on brand equity principles and issues. Report (88-104), 2-4.

81. Simon, C. J., \& Sullivan, M. W. (1993). The measurement and determinants of brand equity: A financial approach. Marketing science, 12(1), 28-52.

82. Smutkupt, P., Krairit, D., \& Ba Khang, D. (2012). Mobile marketing and consumer perceptions of brand equity. Asia Pacific Journal of Marketing and Logistics, 24(4), 539-560

83. Srinivasan, V. (1979). Network models for estimating brand- specific effects in multiattribute marketing models. Management Science, 25(1), 11-21.
84. Srinivasan, V., Park, C. S., \& Chang, D. R. (2005). An approach to the measurement, analysis, and prediction of brand equity and its sources. Management Science, 51(9), 1433-1448

85. Srivastava, R. K., \& Shocker, A. D. (1991). Brand equity: a perspective on its meaning and measurement: Marketing Science Institute.

86. Steenkamp, J.-B. E., \& Van Trijp, H. C. (1991). The use of LISREL in validating marketing constructs. International Journal of Research in marketing, 8(4), 283-299.

87. Thakor, M. V., \& Lavack, A. M. (2003). Effect of perceived brand origin associations on consumer perceptions of quality. Journal of Product \& brand management, 12(6), 394-407.

88. Thorelli, H. B., Lim, J.-S., \& Ye, J. (1989). The relative importance of country of origin, warranty, and retail store image on product evaluations. International Marketing Review, 6(1).

89. Till, B. D., Baack, D., \& Waterman, B. (2011). Strategic brand association maps: developing brand insight. Journal of Product \& brand management, 20(2), 92100.

90. Ulgado, F. M., \& Lee, M. (1993). Consumer evaluations of bi-national products in the global market. Journal of International Marketing, 5-22.

91. Verlegh, P. W., \& Steenkamp, J.-B. E. (1999). A review and meta-analysis of country-of-origin research. Journal of economic psychology, 20(5), 521-546.

92. Yoo, B., \& Donthu, N. (2002). Testing cross-cultural invariance of the brand equity creation process. Journal of Product \& brand management, 11(6), 380398.

93. Yoo, B., Donthu, N., \& Lee, S. (2000). An examination of selected marketing mix elements and brand equity. Journal of the Academy of Marketing Science, 28(2), 195-211. 